\title{
Atmospheric black carbon and sulfate concentrations in Northeast Greenland
}

\author{
A. Massling ${ }^{1,2}$, I. E. Nielsen ${ }^{1,2}$, D. Kristensen ${ }^{1}$, J. H. Christensen ${ }^{1}$, L. L. Sørensen $^{2}$, B. Jensen ${ }^{1}$, Q. T. Nguyen $^{3}$, \\ J. K. Nøjgaard ${ }^{1,2}$, M. Glasius ${ }^{3,4}$, and H. Skov ${ }^{1,2,5}$ \\ ${ }^{1}$ Department of Environmental Science, Aarhus University, 4000 Roskilde, Denmark \\ ${ }^{2}$ Arctic Research Centre, Aarhus University, 8000 Aarhus, Denmark \\ ${ }^{3}$ Department of Chemistry, Aarhus University, 8000 Aarhus, Denmark \\ ${ }^{4}$ Interdisciplinary Nanoscience Centre, Aarhus University, 8000 Aarhus, Denmark \\ ${ }^{5}$ Institute of Chemical Engineering and Biotechnology and Environmental Technology, \\ University of Southern Denmark, 5230 Odense, Denmark
}

Correspondence to: A. Massling (anma@dmu.dk)

Received: 8 December 2014 - Published in Atmos. Chem. Phys. Discuss.: 17 April 2015

Revised: 28 July 2015 - Accepted: 29 July 2015 - Published: 28 August 2015

\begin{abstract}
Measurements of equivalent black carbon (EBC) in aerosols at the high Arctic field site Villum Research Station (VRS) at Station Nord in North Greenland showed a seasonal variation in EBC concentrations with a maximum in winter and spring at ground level. Average measured concentrations were about $0.067 \pm 0.071$ for the winter and $0.011 \pm 0.009$ for the summer period. These data were obtained using a multi-angle absorption photometer (MAAP). A similar seasonal pattern was found for sulfate concentrations with a maximum level during winter and spring analyzed by ion chromatography. Here, measured average concentrations were about $0.485 \pm 0.397$ for the winter and $0.112 \pm 0.072$ for the summer period. A correlation between EBC and sulfate concentrations was observed over the years 2011 to 2013 stating a correlation coefficient of $R^{2}=0.72$. This finding gives the hint that most likely transport of primary emitted BC particles to the Arctic was accompanied by aging of the aerosols through condensational processes. $\mathrm{BC}$ and sulfate are known to have only partly similar sources with respect to their transport pathways when reaching the high Arctic. Aging processes may have led to the formation of secondary inorganic matter and further transport of BC particles as cloud processing and further washout of particles is less likely based on the typically observed transport patterns of air masses arriving at VRS. Additionally, concentrations of EC (elemental carbon) based on a thermo-optical method were determined and compared to EBC measure-
\end{abstract}

ments. EBC measurements were generally higher, but a correlation between EC and EBC resulted in a correlation coefficient of $R^{2}=0.64$.

Model estimates of the climate forcing due to $\mathrm{BC}$ in the Arctic are based on contributions of long-range transported $\mathrm{BC}$ during spring and summer. The measured concentrations were here compared with model results obtained by the Danish Eulerian Hemispheric Model, DEHM. Good agreement between measured and modeled concentrations of both $\mathrm{EBC} / \mathrm{BC}$ and sulfate was observed. Also, the correlation between $\mathrm{BC}$ and sulfate concentrations was confirmed based on the model results observed over the years 2011 to 2013 stating a correlation coefficient of $R^{2}=0.74$. The dominant source is found to be combustion of fossil fuel with biomass burning as a minor, albeit significant source.

\section{Introduction}

Black carbon (BC) is a component of the atmospheric aerosol, which originates from incomplete combustion of fossil fuels or waste, flaring or natural and anthropogenic biomass burning (Roberts and Jones, 2004; Stohl et al., 2013; Yttri et al., 2014). Long-range transported BC to the Arctic is an important atmospheric component as it contributes to Arctic haze, which has a significant influence on the Arctic 
radiation budget (Quinn et al., 2008; Hirdmann et al., 2010; Flanner et al., 2007; Wang et al., 2011).

$\mathrm{BC}$ particles and especially aged $\mathrm{BC}$ particles affect the radiation budget directly by scattering and absorbing incoming solar radiation. In case of haze situations the energy can be re-emitted via long-wave radiation (Lubin and Simpson, 1994). In summary, this results in a heating effect below and within the polluted aerosol layer (e.g. AMAP report, 2011). As primary $\mathrm{BC}$ particles are hydrophobic, their cloud condensation nucleus activity is very limited unless they do appear in very large sizes. Particles of inorganic matter have much better potential to act as cloud condensation nuclei $(\mathrm{CCN})$. Nevertheless, after a certain degree of chemical aging BC particles may have taken up inorganic matter and such coating can lead to modified particles with sufficient CCN activity. In this way, aged $\mathrm{BC}$ particles may also affect the radiation budget indirectly by acting as $\mathrm{CCN}$ or ice nuclei (IN) and thereby they may change cloud albedo (Koehler et al., 2009). In addition, deposited BC particles on snow- or ice-covered surfaces have a heating effect in the lower atmosphere due to a lowering of the surface albedo (Quinn et al., 2008; Wang et al., 2011). Such an effect is estimated to cause more rapid melting in the Arctic (Quinn et al., 2008).

Sulfate is another important component of the atmospheric aerosol. Sulfate particles are very efficient in scattering incoming solar radiation resulting in a cooling effect (Crutzen, 2006). These particles are also highly associated with aging processes as they appear as secondary inorganic aerosols, e.g. as $\left(\mathrm{NH}_{4}\right)_{2} \mathrm{SO}_{4}$ or $\mathrm{NH}_{4} \mathrm{HSO}_{4}$ (Seinfeld and Pandis, 2006). Furthermore, inorganic sulfate can react with organic aerosol species to form organosulfates (Liggio and Li, 2006; Surratt et al., 2007), which have also been observed in the Arctic (Hansen et al., 2014). The presence of sulfate also enhances the CCN activity in atmospheric aerosol samples (Quinn and Bates, 2011). Sulfate aerosol plays a major role in the Arctic atmosphere because of the climate impact through the scattering effect and cloud-forming potential. It has previously been shown that the sulfate concentrations observed at the Villum Research Station (VRS) at Station Nord, North Greenland, are dominated by anthropogenic emissions and to a lesser extent are associated with the emission of sea spray particles (Heidam et al., 2004; Nguyen et al., 2013).

Several studies have been conducted to characterize the physico-chemical properties of Arctic haze over the past 30 years (e.g. Heidam et al., 1984, 1999, 2004; Iversen, 1984; Barrie et al., 1989; Skov et al., 2006). Lately, studies have been motivated by the potentially significant climate effects of BC in the Arctic (Sharma et al., 2004, 2006, 2013; Quinn et al., 2008; Law and Stohl, 2007; Hirdman et al., 2010; Wang et al., 2011). It is well established that the Arctic winter and spring atmosphere is more heavily impacted by transport of air pollution from lower latitudes compared to summer (Heidam et al., 2004; Law and Stohl, 2007).

Recent intercomparisons between model results and measurements of northern hemispheric BC concentrations gener- ally show large discrepancies when simulating the seasonality and magnitude of BC in the Arctic (e.g. Koch et al., 2009; Vignati et al., 2010). However, Huang et al., (2010) demonstrated that a reasonable agreement can be obtained between modeled and measured $\mathrm{BC}$ concentrations when focusing in the model on the Arctic.

The main focus of this paper is to present the dynamics and the seasonality of equivalent black carbon/black carbon (EBC/BC), elemental carbon (EC) and sulfate concentrations over a period of 2 years and 3 months at the high Arctic site VRS at Station Nord, North Greenland. In this study the term EC is applied for measurements based on a thermal-optical method whereas EBC is used for measurements based on a light absorption/optical method (Petzold et al., 2013). For black carbon in general and black carbon results based on model outputs we will use the expression BC. Measured EBC and sulfate and modeled BC and sulfate concentrations are compared and the relation between EBC/BC and sulfate is put into context of possible aging and transport mechanisms, which explain the resulting observations. BC and sulfate (precursors of sulfate) can have common sources (e.g. traffic in areas where fuels are not sulfur-free), but they can also originate from different sources (BC from biomass combustion and sulfate from oceanic emissions).

It has to be clarified that measurements reported in this study were made near the surface and that radiative forcing depends on the entire column burden.

\section{Sampling site and experimental}

\subsection{VRS at Station Nord}

At the Danish military station - Station Nord in North Greenland $\left(81^{\circ} 36^{\prime} \mathrm{N}, 16^{\circ} 40^{\prime} \mathrm{W}\right.$, and $24 \mathrm{~m}$ above mean sea level (m.s.l.)) a monitoring station, Villum Research Station (VRS), for atmospheric measurements is located. The main sampling site during this project is a hut (Flygers hut) situated approximately $2.5 \mathrm{~km}$ southeast of the military camp. The hut is equipped with inlets for measuring gases and particles. All measurements presented in this article were carried out at this site except the sampling with a high-volume sampler used further for elemental carbon (EC) analysis, which is described in more detail in a later section.

\subsection{Instrumentation}

\section{MAAP (Multi-Angle Absorption Photometer)}

In the period from May 2011 to August 2013, observations of the aerosol light absorption coefficient have been conducted at VRS at Station Nord (Flygers hut) using the multiangle absorption photometer (MAAP, Model 5012 Thermo Scientific) (described in detail in Petzold and Schönlinner, 2004). The instrument was operated with a sample flow of about $1 \mathrm{~m}^{3} \mathrm{~h}^{-1}$ and the aerosol light absorption coefficient 
was measured at a wavelength of $\lambda=670 \mathrm{~nm}$. The inlet was used without a size cut-off.

Aerosol light absorption coefficients were converted to EBC concentrations using a specific absorption coefficient of $6.6 \mathrm{~m}^{2} \mathrm{~g}^{-1}$, which is a default setting for the MAAP. The specific absorption coefficient is reported to be site-dependent (Petzold et al., 1997; Sharma et al., 2002). The specific absorption coefficient varies strongly with the distance from the source and thus with the aging of the aerosols. We assume that the uncertainty in EBC related to the value of the used specific absorption coefficient can be as large as a factor of 2. According to Petzold et al., (1997) the observed variability ranges from $5 \mathrm{~m}^{2} \mathrm{~g}^{-1}$ in extremely remote areas to $14 \mathrm{~m}^{2} \mathrm{~g}^{-1}$ at urban locations and up to $20 \mathrm{~m}^{2} \mathrm{~g}^{-1}$ at near-street measuring sites in urban areas using an aethalometer operated at a wavelength of $670 \mathrm{~nm}$. A specific absorption coefficient of $10 \mathrm{~m}^{2} \mathrm{~g}^{-1}$ for the Zeppelin measurement station in Norway, Svalbard $\left(78^{\circ} 54^{\prime} \mathrm{N}, 11^{\circ} 53^{\prime} \mathrm{E}\right.$, and $478 \mathrm{~m}$ above m.s.l.) has been reported by Stohl et al., (2007). Also, Sharma et al., (2002) investigated the specific absorption coefficient of BC using a Particle Soot Absorption Photometer (PSAP) and an aethalometer at the Canadian site, Alert, and used a value of about $10 \mathrm{~m}^{2} \mathrm{~g}^{-1}$ for the PSAP. It was stated that this coefficient tended to decrease at more remote sites among six different sites. Additionally, Sharma et al., (2004) investigated the seasonal variability of the specific attenuation coefficient at Alert, Canada, for an aethalometer operated at a wavelength of $880 \mathrm{~nm}$. A value of $19 \mathrm{~m}^{2} \mathrm{~g}^{-1}$ was recommended, but he found a seasonal dependence of the value when comparing it with the graphitic content obtained by thermal analysis. In summer a value of about $29 \mathrm{~m}^{2} \mathrm{~g}^{-1}$ was found. Also, Bond and Bergstrom (2006) reported a value of $7.5 \pm 1.2 \mathrm{~m}^{2} \mathrm{~g}^{-1}$ for freshly emitted (uncoated) soot particles at $550 \mathrm{~nm}$ based on a literature review. However, after emission, condensation processes in the atmosphere lead to coating of the BC particles, which can also enhance the absorption of the particles. Based on Andreae and Gelencsér (2006) the specific absorption coefficient for aged BC particles can exceed the value of $7.5 \mathrm{~m}^{2} \mathrm{~g}^{-1}$ by a factor of 2 . In the light of these findings, a value of $6.6 \mathrm{~m}^{2} \mathrm{~g}^{-1}$ for the specific absorption coefficient was used in this study for a high Arctic remote site, although this value may overestimate the equivalent estimated black carbon concentration. This value is the standard value for the MAAP instrument and it was shown that it matches best in different atmospheric environments when using this instrument (Petzold et al., 2002).

Because of relatively low EBC concentrations especially during summer, $24 \mathrm{~h}$ data for the MAAP were averaged for weekly samples. Combining the noise level of the instrument and the flow uncertainty in the sample flow, we estimated an overall relative uncertainty of $20 \%$ for EBC concentrations. But this estimate does not include any uncertainty of the specific absorption coefficient as discussed above. Data of black carbon concentrations originating from absorption measurements have rather more to be interpreted with respect to the uncertainty of the specific absorption coefficient. Based on the manufacturer's information we calculated that the detection limit for $24 \mathrm{~h} \mathrm{EBC}$ measurements is lower than $0.006 \mu \mathrm{g}$ $\mathrm{EBC}^{-3}$.

\section{HVS (High-Volume Sampler)}

EC concentrations at VRS at Station Nord were determined during the same time period, using a Digitel DHA 80 highvolume sampler (HVS, Digitel/Riemer Messtechnik, Germany) for $\mathrm{PM}_{10}$. The high-volume sampler was operated at a flow rate of $500 \mathrm{~L} \mathrm{~min}^{-1}$ using $150 \mathrm{~mm}$ prebaked quarts fiber filters (Advantec, Japan). The sampling was done in weekly intervals implying $5000 \mathrm{~m}^{3}$ of air were sampled on each filter. The samples were collected at the military station at the edge of the camp at Station Nord located $2.5 \mathrm{~km}$ from the main sampling site (Flygers hut). The location of the highvolume sampler has practical reasons. It was first established to measure the long-range transport of long-lived pesticides where there is no local sources and because there was also not enough power to run a HVS at Flygers Hut. Pollution from the camp with respect to EC cannot be excluded here, but the data having been included in the analysis as a comparison of different techniques still creates new knowledge on the relationships between EC and EBC. As the data are based on weekly average, the data could not be screened for potential local pollution, which typically appears on much shorter time periods and might be contributions from ground transport in the camp, some burning of garbage during small time periods, and the landing, taxi and take-off of airplanes on an irregular schedule.

The carbon analyzer was a thermal-optical OC/EC instrument from Sunset Laboratory Inc. (Tigard, OR, USA). Punches of $2.5 \mathrm{~cm}^{2}$ were cut from the filters and analyzed according to the EUSAAR-2 protocol (Cavalli et al., 2010). Only front filters were available, so it was not possible to correct for possible positive artifacts, where volatile species adsorb to the filter and add to the particulate organic carbon mass. In this regard, OC but not EC may be overestimated and should only be used with great caution. The detection limit of this set up is $0.37 \mu \mathrm{g} \mathrm{C}$ for a $2.5 \mathrm{~cm}^{2}$ filter punch, i.e.

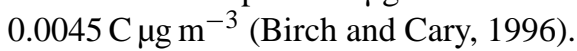

\section{FPS (Filter-Pack Sampler)}

In addition, weekly aerosol samples were collected at the monitoring station VRS (Flygers hut) using a filter-pack sampler (FPS, custom built), which consists of a setup with eight filter packs in series which are operated for a week at a time. An additional filter pack is always taken as a blank. The filter pack consists of three individual filters. The first filter collects particles. The subsequent filters are specially impregnated to collect various gases, notably $\mathrm{SO}_{2}$. The filter pack is described in detail in Skov et al., (2006) and Heidam et al., (2004). A flow of $40 \mathrm{~L} \mathrm{~min}^{-1}$ was sucked through the 
filter-pack sampler and a total of about $400 \mathrm{~m}^{3}$ was sampled on a millipore membrane filter made of mixed cellulose esters. The resulting filters were extracted and analyzed for sulfate using ion chromatography. The technique is described in more detail by Heidam et al., (2004). The uncertainty of the measurements far from the detection limits were better than $20 \%$ expressed as 2 relative standard deviations (Heidam et al., 2004). The detection limit is $0.0015 \mu \mathrm{g} \mathrm{S} \mathrm{m}{ }^{-3}$ for both sulfate and sulfur dioxide.

\section{The Danish Eulerian Hemispheric Model (DEHM)}

The transport and transformation of $\mathrm{BC}$ and sulfate to the Arctic originating from anthropogenic and natural sources outside the Arctic was simulated by DEHM (Christensen, 1997; Christensen et al., 2004; Heidam et al., 2004; Skov et al., 2006; Hole et al., 2009; Brandt et al., 2012). The model system consists of the weather forecast model PSU/NCAR (Pennsylvania State University/National Center for Atmospheric Research) Mesoscale Model version 5 (MM5) modeling subsystem (see Grell et al., 1995). This subsystem is driven by global meteorological data from the European Centre for Medium-Range Weather Forecasts (ECMWF) or National Centers for Environmental Prediction (NCEP). The DEHM model includes two-way nesting capabilities (Frohn et al., 2002).

In this study the model was set up with a horizontal resolution of $150 \mathrm{~km} \times 150 \mathrm{~km}$ south of $60^{\circ} \mathrm{N}$ and a nested grid of $50 \mathrm{~km} \times 50 \mathrm{~km}$ north of $60^{\circ} \mathrm{N}$, both model domains with the North Pole in the center. The vertical resolution was defined on an irregular grid with 29 layers up to approximately $15 \mathrm{~km}$ reflecting the structure of the atmosphere. The basic chemical scheme in DEHM includes 67 different species and is based on the scheme by Strand and Hov (1994). The chemical scheme has been extended with a detailed description of the ammonia chemistry. Furthermore, reactions concerning the wet-phase production of sulfate have been included. The current model describes concentration fields of 58 photochemical compounds (including $\mathrm{NO}_{x}, \mathrm{SO}_{x}, \mathrm{VOC}, \mathrm{NH}_{x}, \mathrm{CO}$, $\mathrm{O}_{3}$ etc.) and several classes of particulate matter, where one class is related to $\mathrm{BC}$. This class comprises of two types of $\mathrm{BC}$ components: freshly emitted $\mathrm{BC}$, which is treated as hydrophobic, and aged coated BC, which is treated as hygroscopic material. The transformation from freshly emitted $\mathrm{BC}$ to aged, coated $\mathrm{BC}$ was treated linearly in the model with a lifetime of freshly emitted BC set to $24 \mathrm{~h}$. Both BC species and sulfate are assumed to be a bulk representation of the particles by a mean particle diameter of $1 \mu \mathrm{m}$. The anthropogenic emissions used are based on the Representative Concentration Pathways emissions (RCP emissions) with a $0.5^{\circ} \times 0.5^{\circ}$ resolution (Lamarque et al., 2010). These emissions from the EMEP expert database (European Monitoring and Evaluation Programme) are used for the areas over Europe with $50 \mathrm{~km} \times 50 \mathrm{~km}$ resolution (Mareck- ova et al., 2008). Furthermore, the biomass burning emissions for the years 1997-2010 are based on the Global Fire Emissions Database version 3 (GFED 3) (van der Werf et al., 2010), which have a horizontal resolution of a $0.5 \times 0.5$ on a monthly time step. For the model runs after 2010 the GFED 3 emissions for 2010 were used. The calculation of the dry deposition velocity is based on the resistance method. The parameterisation of wet deposition is based on a simple scavenging ratio formulation with in-cloud and below-cloud scavenging coefficients for both gas and particulate phase.

There are several uncertainties connected to the model calculations of sulfate and BC which are large and cannot be estimated for this study. The annually averaged anthropogenic emissions of $\mathrm{SO}_{2}$ and $\mathrm{BC}$ were used in the model and these could have an uncertainty of at least $20 \%$ on a yearly basis. These yearly emissions are distributed to daily or hourly emissions using simple time profiles resulting in emissions on shorter timescales having larger uncertainties compared to the total yearly emissions. These time profiles are available as data files from the EMEP model website, (www.emep.int., see also Simpson et al., 2012). The seasonal time profiles are only applied for the European countries. Furthermore, the emissions from biomass burning have even larger uncertainties compared to the anthropogenic emissions. There are also uncertainties associated with predicted three-dimensional wind fields, clouds, precipitation, and turbulence by the MM5 model, especially in the Arctic due to the limited number of meteorological observations inside the Arctic. These uncertainties of the meteorological fields could have a large influence on the total model uncertainties for a transport over several thousand kilometers from sources in mid-latitudes to VRS at Station Nord, for example. Finally there are several parameterizations inside the transport model, which increase the uncertainties: the simple scavenging by precipitation (snow or rain), the turbulence parameterization and the bulk representation of the particles by a particle diameter of $1 \mu \mathrm{m}$.

\section{Results and Discussion}

\subsection{Comparison of EBC and EC concentrations}

Time series of weekly EBC and EC concentrations measured at VRS in the period from May 2011 to August 2013 are presented in Fig. 1a. The maximum concentration of EBC was about $0.34 \mu \mathrm{g} \mathrm{m}^{-3}$ during winter 2012/2013, while the highest EC concentration was found to be $0.13 \mu \mathrm{g} \mathrm{m}^{-3}$ for the same week. Both the EBC and EC weekly minimum concentrations were close to zero. A seasonal variation was observed for EBC and EC with highest concentrations during winter and spring and minimum concentrations during summer.

Generally, Fig. 1a shows good agreement between the patterns of EBC and EC concentrations, however EBC concen- 

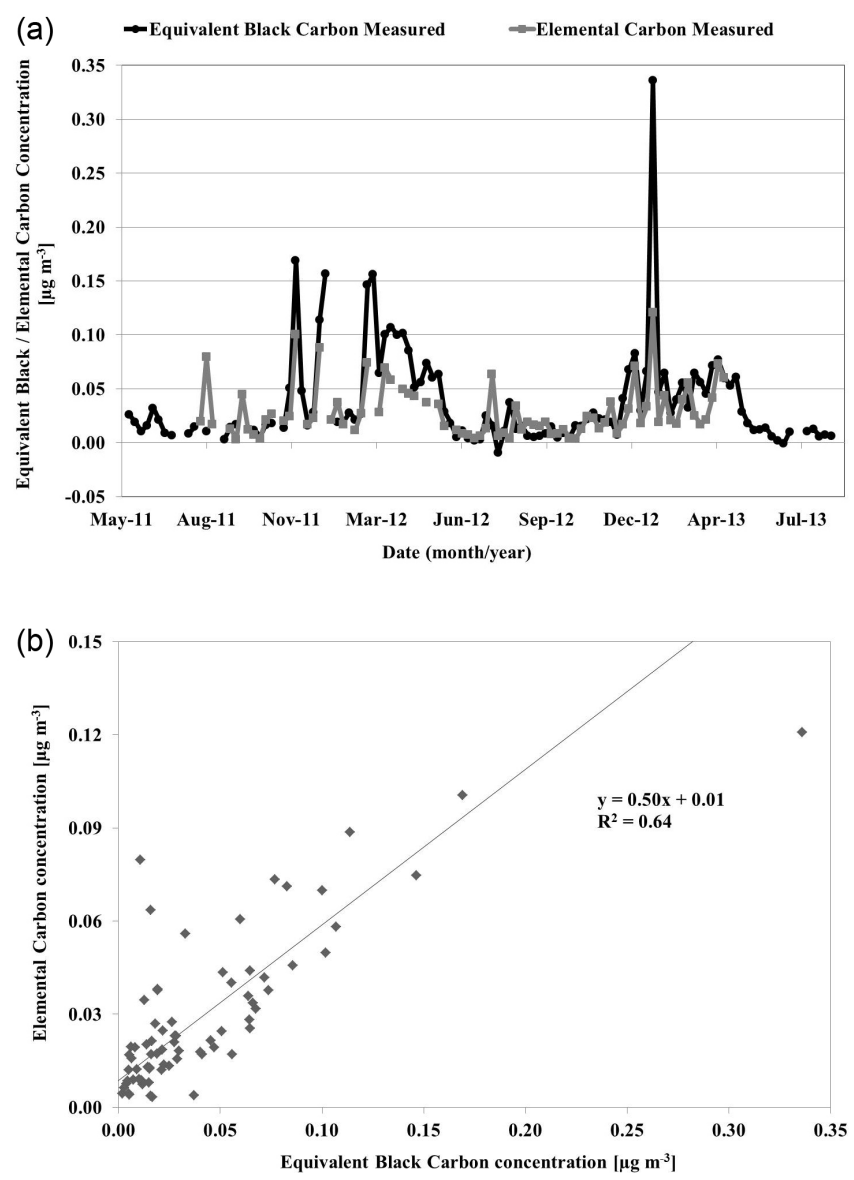

Figure 1. (a) Weekly measured EBC and EC concentrations in $\mu \mathrm{g} \mathrm{m}^{-3}$ from May 2011 to August 2013 at VRS (Station Nord), North Greenland. Both EBC and EC show the same seasonal variation with maximum concentrations in winter and spring and minimum concentrations in summer, (b) scatter plot of measured EC and EBC concentrations (the slope obtained by orthogonal regression is $y=0.50$ showing a correlation coefficient of $R^{2}=0.64$ ).

trations are often higher compared to EC concentrations. Differences between the two parameters are expected since the $\mathrm{EBC}$ and EC concentrations are based on two different measurement techniques which both experience several problems due to different artifacts. In Fig. 1b, the correlation between $\mathrm{EC}$ and EBC is shown resulting in a slope of $y=0.50$ and a correlation coefficient of $R^{2}=0.64$. In principle, the overestimation of EBC in comparison to EC as observed in the time series is reflected in the correlation plot. A further look into seasonal mean values of EBC and EC shows that this overestimation is more pronounced during the winter and spring period when Arctic haze is observed (Table 1). The fraction of OC/EC is almost constant over the seasons and does not give an additional hint that based on specific emissions the fraction of EC might be underestimated for indicative seasons.
The EC/OC carbon analyzer used in this study is based on a thermal-optical method, which corrects for charring that may otherwise overestimate EC. However, artifacts may also arise if samples contain brown carbon $(\mathrm{BrC})$, which is a part of organic carbon that absorbs in the visible and ultraviolet spectral regions (Kirchstetter and Novakov, 2004; Andreae and Gelencsér, 2006). BrC can be volatilized over a broad temperature range and some of the $\mathrm{BrC}$ can be accounted for as EC, hence overestimating the EC concentration (Andreae and Gelencsér, 2006). Another issue is the fact that the combustion temperature of $\mathrm{EC}$ and $\mathrm{BrC}$ can be lowered in the presence of inorganic species, which are sampled on the filter and can catalyze the oxidation of $\mathrm{EC}$ and $\mathrm{BrC}$ (Andreae and Gelencsér, 2006). This can result in misinterpretation of $\mathrm{EC}$ as OC and hence lead to an underestimation of the EC mass concentration. From inspection of Fig. 1, an underestimation of EC could possibly influence the results, whereas volatilization of $\mathrm{BrC}$ on the cost of organic carbon and thus overestimation of EC is not likely to occur.

The difference between EBC and EC concentration could furthermore be explained by the assumption that the measured absorption coefficients by the MAAP is ascribed to EBC. This might not be entirely correct since a minor fraction of the absorption could be caused by $\mathrm{BrC}$ (Andreae and Gelencsér, 2006). Therefore, the higher EBC concentration could be explained by a higher content of $\mathrm{BrC}$. Furthermore, the default specific absorption coefficient for the MAAP of $6.6 \mathrm{~m}^{2} \mathrm{~g}^{-1}$ could be too low since previous studies suggest an enhancement of the absorption coefficient of aged aerosols due to coating, which can increase the specific absorption coefficient by a factor of two or more (Andreae and Gelencsér, 2006). This would contribute to an overestimation of the EBC concentration which could help explain the discrepancy between our EBC and EC concentrations. In fact, Petzold et al., (1997) found the specific absorption coefficient varying within a wide range when summarizing published values from a number of different studies including different locations and thus different aging status of the observed aerosol. Additionally, soil dust is also known to have absorbing characteristics (Fialho et al., 2005), which might enhance the estimated EBC concentration when present in the observed aerosol. The MAAP was operated with no size cut-off so that the detection of soil dust cannot be excluded, while the EC measurements had a particle size cut-off of $10 \mu \mathrm{m}$ in diameter.

Another explanation for occasionally observed differences could be that measurements of EBC and EC were not being conducted at the exact same location. The HVS, used to sample EC, was located at Station Nord in the military camp whereas the MAAP was installed approximately $2.5 \mathrm{~km}$ from the station (Flygers hut). This could explain why the EC concentrations occasionally exceed the EBC concentrations since these higher values could originate from local pollution events in the military camp at Station Nord, though it 
Table 1. Mean measured and modeled EBC/BC and sulfate concentrations together with mean measured EC and OC concentrations during the different seasons at VRS (Station Nord), North Greenland between May 2011 and August 2013.

\begin{tabular}{lllllll}
\hline & $\begin{array}{l}\text { EBC } \\
\text { measured } \\
{\left[\mu \mathrm{g} \mathrm{m}^{-3}\right]}\end{array}$ & $\begin{array}{l}\text { Sulfate } \\
\text { measured } \\
{\left[\mu \mathrm{g} \mathrm{m}^{-3}\right]}\end{array}$ & $\begin{array}{l}\mathrm{BC} \\
\text { modeled } \\
{\left[\mu \mathrm{g} \mathrm{m}^{-3}\right]}\end{array}$ & $\begin{array}{l}\text { Sulfate } \\
\text { modeled } \\
{\left[\mu \mathrm{g} \mathrm{m}^{-3}\right]}\end{array}$ & $\begin{array}{l}\text { EC } \\
\text { measured } \\
{\left[\mu \mathrm{g} \mathrm{m}^{-3}\right]}\end{array}$ & $\begin{array}{l}\text { OC } \\
\text { measured } \\
{\left[\mu \mathrm{g} \mathrm{m}^{-3}\right]}\end{array}$ \\
\hline $\begin{array}{l}\text { Summer (June, July, } \\
\text { August) }\end{array}$ & $0.011 \pm 0.009$ & $0.112 \pm 0.072$ & $0.019 \pm 0.013$ & $0.144 \pm 0.097$ & $0.020 \pm 0.022$ & $0.151 \pm 0.079$ \\
\hline $\begin{array}{l}\text { Autumn (September, } \\
\text { October, November) }\end{array}$ & $0.022 \pm 0.034$ & $0.138 \pm 0.120$ & $0.011 \pm 0.015$ & $0.317 \pm 0.398$ & $0.019 \pm 0.020$ & $0.144 \pm 0.077$ \\
\hline $\begin{array}{l}\text { Winter (December, } \\
\text { January, February) }\end{array}$ & $0.067 \pm 0.071$ & $0.485 \pm 0.397$ & $0.040 \pm 0.033$ & $0.900 \pm 0.657$ & $0.036 \pm 0.028$ & $0.202 \pm 0.149$ \\
\hline $\begin{array}{l}\text { Spring (March, } \\
\text { April, May) }\end{array}$ & $0.054 \pm 0.029$ & $0.480 \pm 0.243$ & $0.022 \pm 0.017$ & $0.618 \pm 0.582$ & $0.042 \pm 0.018$ & $0.245 \pm 0.061$ \\
\hline Total no. of samples & 106 & 94 & 119 & 119 & 78 & 78 \\
\hline
\end{tabular}

is manned with 5 permanent staff and consequently has very low emissions.

\subsection{Seasonal variation of measured EBC and sulfate concentrations}

Figure 2 shows the weekly time series of EBC and sulfate concentrations measured at VRS between May 2011 and August 2013. Sulfate maximum concentrations were up to $1.746 \mu \mathrm{g} \mathrm{m}^{-3}$ for weekly mean values coinciding with the maximum value during the study period of black carbon concentration at about $0.336 \mu \mathrm{g} \mathrm{m}^{-3}$ (only one data point as indicated in Fig. 2). Minimum sulfate concentrations were close to or below the detection limit and appeared simultaneously with the minimum of equivalent black carbon concentrations which were also close or below the detection limit. A clear seasonal pattern was observed for both EBC and sulfate with maximum concentrations in winter/spring and minimum concentrations in summer each year (Fig. 2). The observed pattern for sulfate is identical with previous observations at VRS (Heidam et al., 2004).

In comparison, reported $\mathrm{BC}$ concentrations from the field stations Alert, Canada $\left(82.5^{\circ} \mathrm{N}, 62.3^{\circ} \mathrm{W}, 210 \mathrm{~m}\right.$ a.s.1.), and Zeppelin on Svalbard, Norway $\left(78.9,11.9^{\circ}\right.$ E, 478 m a.s.1.), exhibit similar seasonal patterns as observed at Station Nord (AMAP report, 2011; Sharma et al., 2013). At the Alert field station the highest $\mathrm{BC}$ concentrations were found to be up to $0.089 \mu \mathrm{g} \mathrm{m}^{-3}$ and at the Zeppelin field station on Svalbard the highest BC concentrations were found up to $0.082 \mu \mathrm{g} \mathrm{m}^{-3}$ during winter/spring 2007/2008. During the following winter/spring (2008/2009) the maximum BC concentration at the Zeppelin field station reached values up to only $0.036 \mu \mathrm{g} \mathrm{m}^{-3}$. This is in good agreement with values found in this study for a later time period regarding the typical winter and spring maximum values.

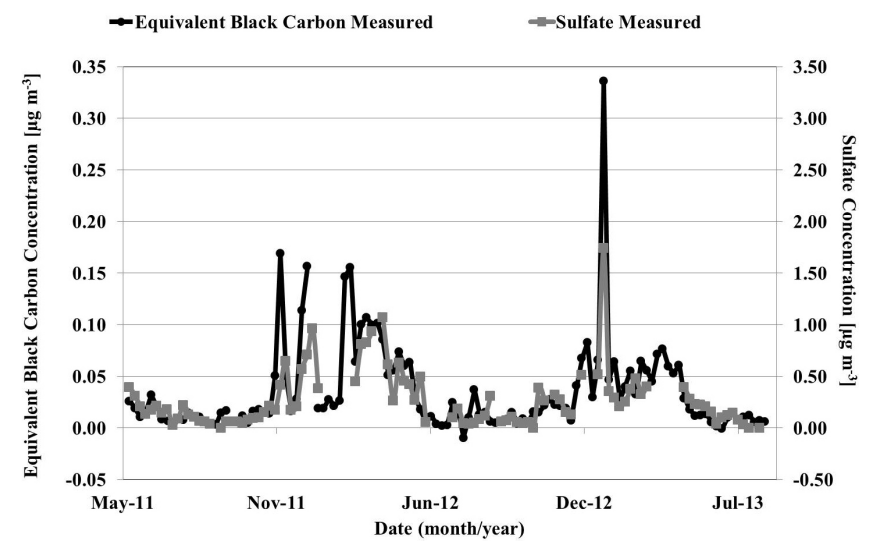

Figure 2. Weekly measured EBC and sulfate concentrations in $\mu \mathrm{g} \mathrm{m}^{-3}$ from May 2011 to August 2013 at VRS (Station Nord), North Greenland. Here, EBC and sulfate concentrations exhibit very similar patterns with maximum concentrations in winter and spring compared to minimum concentrations in summer.

Mean concentrations of measured EBC at VRS during winter (measurement period: December to February) were about $0.067 \pm 0.071 \mu \mathrm{g} \mathrm{m}^{-3}$ compared to the summer (measurement period: June to August) where mean values were about $0.011 \pm 0.009 \mu \mathrm{g} \mathrm{m}^{-3}$. In contrast, the corresponding values for sulfate were $0.485 \pm 0.397 \mu \mathrm{g} \mathrm{m}^{-3}$ for winter and about $0.112 \pm 0.072 \mu \mathrm{g} \mathrm{m}^{-3}$ for summer during the measurement period. The values are also listed in Table 1 .

The ratio between sulfate and EBC is a little lower in autumn and winter compared to spring and summer, but does not give a hint that biomass contribution may have a significant impact on the distribution between sulfate and EBC during special time periods. This is different with regard to the ratio between sulfate and EC where lower values are observed during summer and autumn, which might be indicative for biomass burning during, e.g. the summer period as 


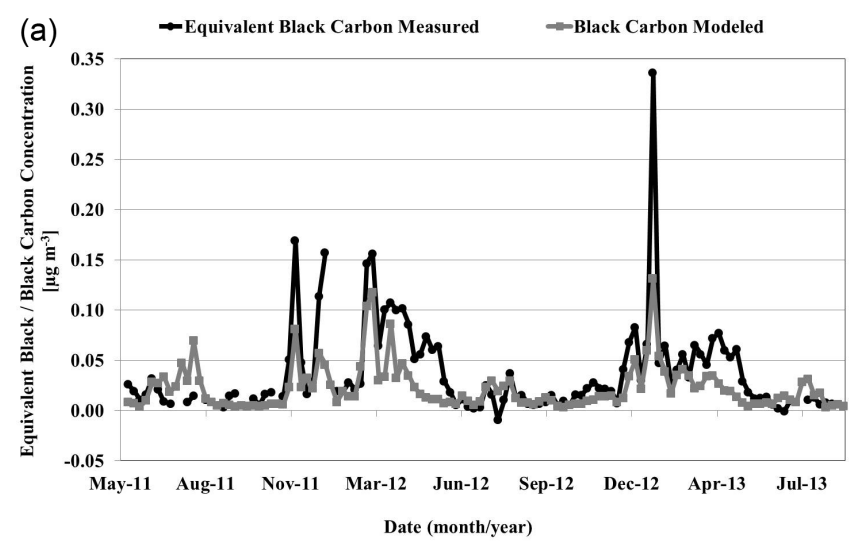

(b)

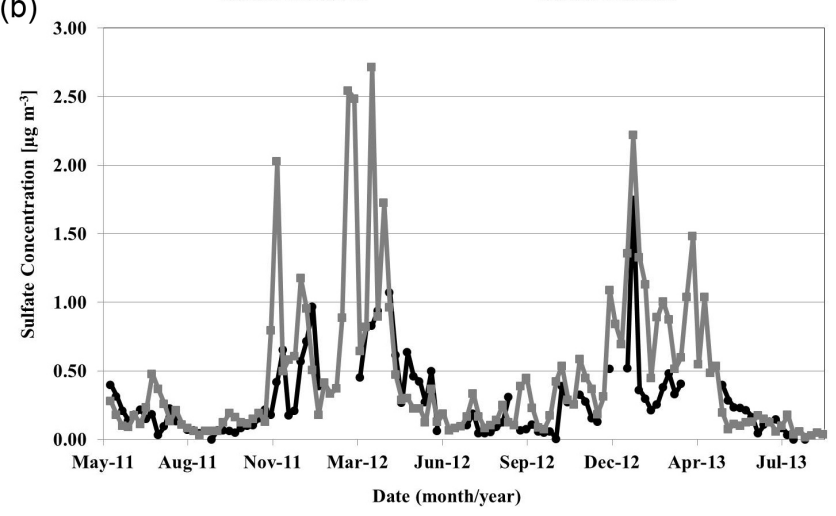

Figure 3. Comparison of measurement and model results from DEHM for (a) EBC/BC and (b) sulfate concentrations at VRS (Station Nord), North Greenland, during the time period from May 2011 to August 2013.

only minor emissions from sulfate are expected from this source compared to black carbon.

\subsection{Comparison of measured and modeled EBC/BC and sulfate concentrations}

The results of modeled $\mathrm{BC}$ and modeled sulfate concentrations from DEHM are presented together with the corresponding measurements of EBC and sulfate observed at VRS in the period from May 2011 to August 2013 in Fig. 3a and b. The examined EBC/BC and sulfate concentrations exhibit very similar patterns characterized by higher concentrations in winter/spring compared to summer, which is in accordance with the seasonal cycle of Arctic Haze observed in Arctic regions by several authors (Heidam et al., 1984, 1999, 2004; Iversen et al., 1984; Barrie et al., 1989; Stohl et al., 2007).

In general, it can be concluded that the seasonal variation of both species is reproduced well by the model. For VRS, the EBC measurements state seasonal mean values which are about a factor of 1.5 to 2.5 higher compared with the $\mathrm{BC}$ model results during winter and spring. On the other hand the model seems to overestimate the measured sulfate concentra- tions (seasonal mean values) in autumn, winter, and spring by a factor between 1.3 and 2.3.

Discrepancies seen for EBC/BC (Fig. 3a) can be explained by the larger uncertainties of emission inventories used as input for the model of BC compared to emission inventories of sulfur dioxide and sulfate with relation to both the total amount and the temporal and geographical variations. Another important reason for these discrepancies could be due to model inadequacy in the model description of the physics, e.g the bulk external mixed representation of the particles. For example, there is little information known about the daily and seasonal activity pattern concerning $\mathrm{BC}$ emissions, which is also reflected in the uncertainty of the emission inventories. Emissions from wild and agricultural fires are calculated based on GFED data (Global Fire Emissions Database) on a monthly basis. Emission events rarely last a month and higher resolution data are urgently required, which is expected to improve the agreement between measured and modeled EBC/BC concentrations.

Previous studies comparing measured and modeled values for a 10-year period at Station Nord suggested that DEHM in general describes the sulfate concentrations in the Arctic well (Heidam et al., 1999, 2004; Christensen, 1997) which is also apparent from Fig. 3b. Nevertheless, the model performance for the studied period is not as good as for previous years. The reason for that might be changes in the interannual emissions, which have not yet been incorporated in the model. Measurements of sulfate at VRS show a large decrease of more than a factor of two with respect to the yearly mean concentrations from 2008 to 2012, while the model concentrations have only a small variability $( \pm 10-20 \%)$. The emissions data in the model were the best available estimate up to date.

The seasonality of air pollutants at Station Nord occurs predominantly because of specific transport patterns of air masses, which are highly related to the location and extension of the polar vortex. Thus, transport of pollution into the Arctic boundary layer from mid-latitudes is much more likely in winter and spring compared to summer. These seasonal patterns are well reproduced for $\mathrm{EBC} / \mathrm{BC}$ and sulfate concentrations by the measurement and model results.

Mean concentrations of modeled BC at VRS during winter (December to February) were about $0.040 \pm 0.033 \mu \mathrm{g} \mathrm{m}^{-3}$ compared to summer (June to August) where mean values were about $0.019 \pm 0.013 \mu \mathrm{g} \mathrm{m}^{-3}$. In contrast, the corresponding modeled values for sulfate in winter were $0.900 \pm 0.657$ and about $0.144 \pm 0.097 \mu \mathrm{g} \mathrm{m}^{-3}$ for the summer period. The values are also listed in Table 1.

\subsection{Atmospheric processing of $\mathrm{BC}$ and sulfate in the Arctic}

Orthogonal regression was applied separately to the measured and modeled data of $\mathrm{EBC} / \mathrm{BC}$ and sulfate concentrations. The $\mathrm{EBC} / \mathrm{BC}$ and sulfate concentrations were found 
to correlate with an $R^{2}$ correlation coefficient of 0.84 for the measured values (Fig. 4a) and correspond to a value of $R^{2}$ correlation coefficient of 0.85 for the modeled values (Fig. 4b). Pure BC atmospheric particles are known to be primarily emitted, whereas sulfate aerosol is a combination of minor contributions of primary emitted sulfate aerosol and dominated by secondary inorganic aerosol formation favored by the photo-oxidation of sulfur dioxide. For VRS at Station Nord it has previously been shown that anthropogenic emissions of sulfur dioxide and sulfate is the main source of sulfate aerosol by application of the COnstrained Physical REceptor Model (COPREM) and the Danish Eulerian Hemispheric Model (DEHM) (Heidam et al., 2004). The results suggested that photo-oxidation of dimethyl sulfide (DMS) and sea-salt sulfate plays a minor role in winter and spring time. In summer time, the relative contribution from DMS to sulfate might be larger. A recent study by Nguyen et al., (2013) at Station Nord (VRS) also suggests that sulfate aerosol and sulfur dioxide predominantly originate from anthropogenic emissions such as Siberian metal smelters and other long-range transported anthropogenic pollution.

The positive correlation between $\mathrm{EBC} / \mathrm{BC}$ and sulfate concentrations at VRS indicates that they undergo a similar transport pattern despite having partly different sources. Also, the simultaneous emission of $\mathrm{BC}$ and sulfate favors a positive correlation of the two species at the remote Arctic site. However, BC is known to be emitted in the submicrometer size regime. The particles can either grow by condensation or coagulation and in this way reach sizes around $0.5 \mu \mathrm{m}$ in aerodynamic diameter where they have the longest atmospheric life times and thus can be transported over the longest distances (Seinfeld and Pandis, 2006; Huang et al., 2010). It should be added that BC emitted from, e.g., biomass combustion is supposed to have larger sizes of up to a few hundred nanometers in diameter compared to $\mathrm{BC}$ originated from, e.g., traffic, which is supposed to have sizes of up to only one hundred nanometers in diameter.

Since BC and sulfate are only partly related to the same combustion sources during winter and spring, we hypothesize that sulfate particles function as transport containers for $\mathrm{BC}$ matter as the concentration of sulfate is clearly dominating and mostly formed in secondary processes. Although our study does not investigate the state of mixing of observed aerosols, it is most likely that sulfate and BC are internally mixed as BC appears aged only short time after release, which can be indicated by its loss of hydrophobic character (Swietlicki et al., 2008).

By comparing the scatter plots of measured (Fig. 4a) and modeled (Fig. 4b) values, it is apparent that the DEHM model for VRS results in similar correlation coefficients between sulfate and $\mathrm{BC}$ as observed for the measurements between sulfate and EBC as mentioned above. The slopes of the two correlations $y=5.86$ (measurement results) and $y=24.15$ (model results) obtained by orthogonal regression are on the contrary rather different from each other stat-
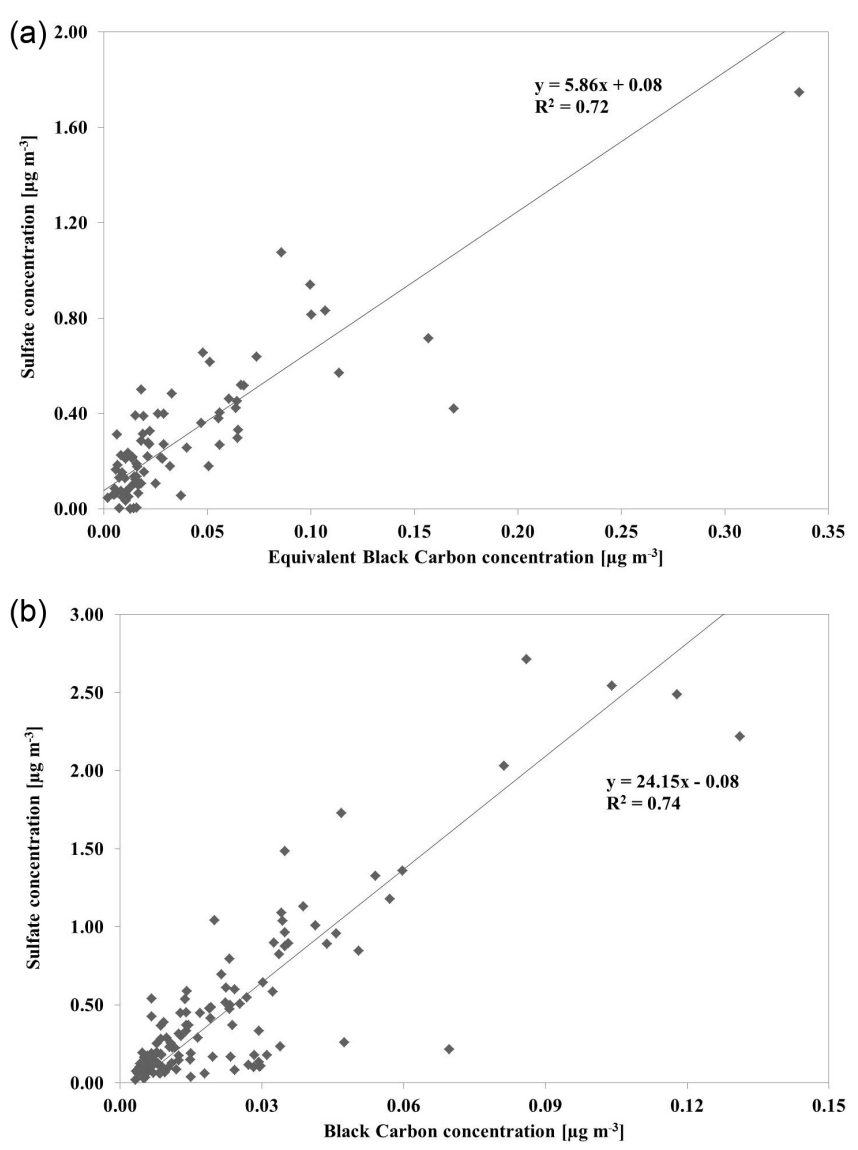

Figure 4. Scatter plot of EBC/BC and sulfate concentrations based on (a) measurement results (the slope obtained by orthogonal regression between sulfate and EBC is $y=5.86$ showing a correlation coefficient of $R^{2}=0.72$ ) and (b) model results (the slope obtained by orthogonal regression between sulfate and BC is $y=24.15$ showing a correlation coefficient of $R^{2}=0.74$ ) during May 2011 to August 2013 at VRS (Station Nord), North Greenland.

ing that from the perspective of measurement results concentrations of sulfate aerosol are by a factor of about six higher compared to concentrations of equivalent black carbon aerosol whereas model results state concentrations of sulfate aerosol are by a factor of 24 higher.

Assuming that particles at VRS arrive as internally mixed particles composed of black carbon, sulfate and some other inorganic and organic species, a freshly emitted primary BC particle might experience a substantial diameter growth during long-range transport to the Arctic, prolonging its lifetime in relation to dry deposition, because the dry deposition velocity for small particles (50 to $100 \mathrm{~nm}$ in size) decreases with increasing diameters up to approximately $0.5 \mu \mathrm{m}$ (Slinn and Slinn, 1980; Slinn, 1982) and therewith increasing its probability to reach the Arctic. Also, in general, a low deposition rate is observed during the Arctic winter enhancing the long-range transport of air pollutants. 
On the other hand, any up-take of soluble material and implied change from hydrophobic to hydrophilic character also enhances the chance of the particle to get involved in a cloud process and thus the chance for wet deposition. But the main pathway in the lower troposphere for Arctic Haze during winter and spring is from sources north of the Arctic Front in northern Eurasia over snow- or ice-covered surfaces (Stohl, 2006; Christensen, 1997). This atmospheric transport is highly episodic and often related to large-scale blocking events over Siberia and with none or only a small amount of precipitation events during the transport episodes (Raatz and Shaw, 1984; Christensen, 1997). This means even though the increased hydrophilic character of $\mathrm{BC}$ tends to decrease the lifetime, the wet deposition is still small during the transport episodes.

The described circumstances also indicate that the source areas for $\mathrm{BC}$ and $\mathrm{SO}_{2}$ (precursor for sulfate aerosol) are similar, especially during the winter and spring time and the removal processes of $\mathrm{BC}$ and sulfate are also similar to a certain extent.

\section{Summary and conclusions}

The characteristics of Arctic air pollution with respect to $\mathrm{EBC} / \mathrm{BC}, \mathrm{EC}$ and sulfate aerosol observed at the high Arctic site, Villum Research Station at Station Nord, for a period of 2 years and 3 months was investigated in this study to improve our understanding of the particle dynamics in relation to their properties, life times and mutual dependencies.

EBC and EC concentrations followed the same pattern, but measured concentrations values of $\mathrm{EBC}$ were about a factor of 2 higher which is explained by the limits of the different techniques. Measurements together with model results were used to estimate the concentration levels and the seasonal variation of $\mathrm{EBC} / \mathrm{BC}$ and sulfate to the Arctic and to understand the interplay of the two species during transport to the Arctic region. Measured EBC concentrations showed average concentrations of $0.067 \mu \mathrm{g} \mathrm{m}^{-3}$ in winter and $0.011 \mathrm{\mu g} \mathrm{m}^{-3}$ in summer compared to values of $0.485 \mu \mathrm{g} \mathrm{m}^{-3}$ in winter and $0.112 \mu \mathrm{g} \mathrm{m}^{-3}$ in summer for sulfate. Corresponding modeled values were 0.040 in winter and $0.019 \mu \mathrm{g} \mathrm{m}^{-3}$ in summer for BC and 0.900 in winter and $0.144 \mu \mathrm{g} \mathrm{m}^{-3}$ in summer for sulfate.

It was found that $\mathrm{EBC} / \mathrm{BC}$ and sulfate concentrations exhibit very similar patterns, characterized by higher concentrations in winter/spring compared to summer, which is in accordance with the seasonal cycle of Arctic Haze and its annual variation. This was found in both measurement and model results.

A comparison of measured and modeled concentrations of $\mathrm{EBC} / \mathrm{BC}$ and sulfate has been carried out. The results show good agreement between the measured and modeled concentrations of both species with respect to their seasonal pattern indicating that the model is able to describe the strong sea- sonal variation of both $\mathrm{BC}$ and sulfate concentrations. Nevertheless, the relationship in mass ratio between sulfate and $\mathrm{EBC} / \mathrm{BC}$ is observed to be much lower for the measurement results compared to the model results. The most likely reason for this discrepancy is the overestimation of modeled sulfate concentrations, which is probably due to changes in the interannual emissions of $\mathrm{SO}_{2}$, which have not been included in the used emissions inventories. Model results from earlier years do not show this large overestimation.

A specific relationship between sulfate concentrations and $\mathrm{EBC} / \mathrm{BC}$ was observed for the entire study period. This indicates that both species undergo a common aging process, which predominantly leads to accumulation of $\mathrm{BC}$ and sulfate containing particles following the same transport pattern to the high Arctic. Sulfate aerosol seems to function as transport container for BC matter. In this way, particles are composed of a mixture of carbonaceous and inorganic material and reach sizes enhancing their lifetime giving the possibility to be transported over long distances in the atmosphere reaching eventually e.g. the high Arctic. A low deposition rate during the Arctic winter is most likely supporting this process.

For more understanding of aerosol aging processes during long-range transport from Eurasia and North America to the Arctic environment it will be highly relevant to get more information on the size segregated chemical composition of Arctic submicrometer aerosols.

Author contributions. A. Massling prepared the manuscript with contributions from all co-authors. I. E. Nielsen and D. Kristensen analyzed the filters for EC measurements, I. E. Nielsen evaluated the MAAP measurements and provided a literature review for the article. Q. T. Nguyen prepared the instruments for analysis and calibrated those. H. Skov and L. L. Sørensen designed the experiments. J. K. Nøjgaard and M. Glasius and supervised the data analysis, J. K. Nøjgaard controlled the carbon analysis. B. Jensen installed the sampling techniques and carried out the experiments. J. H. Christensen developed the model code and performed the simulations. All authors have contributed to revising the manuscript and have approved the final version.

Acknowledgements. This work was financially supported by "The Danish Environmental Protection Agency" with means from the MIKA/DANCEA funds for Environmental Support to the Arctic Region. The Nordic Centre of Excellence CRAICC and EU 7th Framework program is acknowledged for financial support. The Royal Danish Air Force is acknowledged for providing free transport to Station Nord, and the staff at Station Nord is especially acknowledged for excellent support. Villum Foundation is acknowledged for the large grant making it possible to build the new research station, Villum Research Station (VRS), at Station Nord.

Edited by: A. Stohl 


\section{References}

AMAP report, Arctic Monitoring and Assessment Programme: The Impact of Black Carbon on Arctic Climate, edited by: Quinn, P. K., Stohl, A., Arneth, A., Berntsen, T., Burkhart, J. F., Christensen, J., Flanner, M., Kupiainen, K., Lihavainen, H., Shepherd, M., Shevchenko, V., Skov, H., and Vestreng, V.: Norwegian Institute for Air Research, Oslo, 72 pp., 2011.

Andreae, M. O. and Gelencsér, A.: Black carbon or brown carbon?, The nature of light-absorbing carbonaceous aerosols, Atmos. Chem. Phys., 6, 3131-3148, doi:10.5194/acp-6-3131-2006, 2006.

Barrie, L. A., den Hartog, G., Bottenheim, J. W., and Landsberger, S.: Anthropogenic aerosols and gases in the lower troposphere at Alert Canada in April 1086, J. Atmos. Chem., 9, 101-127, 1989.

Birch, M. E. and Cary, R. A.: Elemental carbon-based method for monitoring occupational exposures to particulate diesel exhaust, Aero. Sci. Technol., 25, 221-241, 1996.

Bond, T. C. and Bergstrom, R. W.: Light Absorption by Carbonaceous Particles: An Investigative Review, Aero. Sci. Technol., 40, 27-67, 2006.

Brandt, J., Silver, J. D., Frohn, L. M., Geels, C., Gross, A., Hansen, A. B., Hansen, K. M., Hedegaard, G. B., Skjøth, C. A. Villadsen, H., Zare, A., and Christensen, J. H.: An integrated model study for Europe and North America using the Danish Eulerian Hemispheric Model with focus on intercontinental transport, Atmos. Environ., 53, 156-176, 2012.

Cavalli, F., Viana, M., Yttri, K. E., Genberg, J., and Putaud, J.-P.: Toward a standardised thermal-optical protocol for measuring atmospheric organic and elemental carbon: the EUSAAR protocol, Atmos. Meas. Tech., 3, 79-89, doi:10.5194/amt-3-79-2010, 2010.

Christensen, J. H.: The Danish Eulerian hemispheric model - A three-dimensional air pollution model used for the Arctic, Atmos. Environ., 31, 4169-4191, 1997.

Christensen, J. H., Brandt, J., Frohn, L. M., and Skov, H.: Modelling of Mercury in the Arctic with the Danish Eulerian Hemispheric Model, Atmos. Chem. Phys., 4, 2251-2257, doi:10.5194/acp-42251-2004, 2004.

Crutzen, P.: Albedo enhancement by stratospheric sulfur injections: A contribution to resolve a policy dilemma?, Climatic Change, 77, 211-219, 2006.

Fialho, P., Hansen, A. D. A., and Honrath, R. E.: Absorption coef?cients by aerosols in remote areas: a new approach to decouple dust and black carbon absorption coef?cients using sevenwavelength Aethalometer data, J. Aerosol Sci., 36, 267-282, 2005

Flanner, M. G., Zender, C. S., Randerson, J. T., and Rasch, P. J.: Present-day climate forcing and response from black carbon in snow, J. Geophys. Res. Atmos., 112, D11202, doi:10.1029/2006JD008003, 2007.

Frohn, L. M., Christensen, J. H., and Brandt, J.: Development of a high-resolution nested air pollution model - The numerical approach, J. Comput. Phys., 179, 68-94, 2002.

Grell, G. A., Dudhia J., and Stauffer D. R.: A Description of the Fifth-Generation Penn State/NCAR Mesoscale Model (MM5), NCAR/TN-398+STR. NCAR Technical Note, Mesoscale and Microscale Meteorology Division, National Center for Atmospheric Research, Boulder, Colorado, 122 pp., 1995.
Hansen, A. M. K., Kristensen, K., Nguyen, Q. T., Zare, A., Cozzi, F., Nøjgaard, J. K., Skov, H., Brandt, J., Christensen, J. H., Ström, J., Tunved, P., Krejci, R., and Glasius, M.: Organosulfates and organic acids in Arctic aerosols: speciation, annual variation and concentration levels, Atmos. Chem. Phys., 14, 7807-7823, doi:10.5194/acp-14-7807-2014, 2014.

Heidam, N. Z.: The Components of the Arctic Aerosol, Atmos. Environ., 18, 329-343, 1984.

Heidam, N. Z., Wåhlin, P., and Christensen, J. H.: Tropospheric gases and aerosols in northeast Greenland, J. Atmos. Sci., 56, 261-278, 1999.

Heidam, N. Z., Christensen, J., Wåhlin, P., and Skov, H.: Arctic atmospheric contaminants in NE Greenland: levels, variations, origins, transport, transformations and trends 1990-2001, Sci. Total Environ., 331, 5-28, 2004.

Hirdman, D., Burkhart, J. F., Sodemann, H., Eckhardt, S., Jefferson, A., Quinn, P. K., Sharma, S., Ström, J., and Stohl, A.: Longterm trends of black carbon and sulphate aerosol in the Arctic: changes in atmospheric transport and source region emissions, Atmos. Chem. Phys., 10, 9351-9368, doi:10.5194/acp-10-93512010, 2010.

Hole, L. R., Christensen, J. H., Ruoho-Airola, T., Tørseth, K., Ginzburg, V., and Glowacki, P.: Past and future trends in concentrations of sulphur and nitrogen compounds in the Arctic, Atmos. Environ., 43, 928-939, 2009.

Huang, L., Gong, S. L., Jia, C. Q., and Lavoue, D.: Importance of deposition processes in simulating the seasonality of the Arctic black carbon aerosol, J. Geophys. Res., 115, D17207, doi:10.1029/2009JD013478, 2010.

Iversen, T.: On the Atmospheric Transport of Pollution to the Arctic, Geophys. Res. Lett., 11, 457-460, 1984.

Kirchstetter, T. W., Novakov, T., and Hobbs, P. V.: Evidence that the spectral dependence of light absorption by aerosols is affected by organic, J. Geophys. Res., 109, D21208, doi:10.1029/2004JD004999, 2004

Koch, D., Schulz, M., Kinne, S., McNaughton, C., Spackman, J. R., Balkanski, Y., Bauer, S., Berntsen, T., Bond, T. C., Boucher, O., Chin, M., Clarke, A., De Luca, N., Dentener, F., Diehl, T., Dubovik, O., Easter, R., Fahey, D. W., Feichter, J., Fillmore, D., Freitag, S., Ghan, S., Ginoux, P., Gong, S., Horowitz, L., Iversen, T., Kirkevåg, A., Klimont, Z., Kondo, Y., Krol, M., Liu, X., Miller, R., Montanaro, V., Moteki, N., Myhre, G., Penner, J. E., Perlwitz, J., Pitari, G., Reddy, S., Sahu, L., Sakamoto, H., Schuster, G., Schwarz, J. P., Seland, Ø., Stier, P., Takegawa, N., Takemura, T., Textor, C., van Aardenne, J. A., and Zhao, Y.: Evaluation of black carbon estimations in global aerosol models, Atmos. Chem. Phys., 9, 9001-9026, doi:10.5194/acp-9-9001-2009, 2009.

Koehler, K. A., DeMott, P. J., Kreidenweis, S. M., Popovicheva, O. B., Petters, M. D., Carrico, C. M., Kireeva, E. D. Khokhlova, T. D., and Shonija, N. K.: Cloud condensation nuclei and ice nucleation activity of hydrophobic and hydrophilic soot particles, Phys. Chem. Chem. Phys., 11, 7906-7920, 2009.

Lamarque, J.-F., Bond, T. C., Eyring, V., Granier, C., Heil, A., Klimont, Z., Lee, D., Liousse, C., Mieville, A., Owen, B., Schultz, M. G., Shindell, D., Smith, S. J., Stehfest, E., Van Aardenne, J., Cooper, O. R., Kainuma, M., Mahowald, N., McConnell, J. R., Naik, V., Riahi, K., and van Vuuren, D. P.: Historical (1850-2000) gridded anthropogenic and biomass burning 
emissions of reactive gases and aerosols: methodology and application, Atmos. Chem. Phys., 10, 7017-7039, doi:10.5194/acp10-7017-2010, 2010.

Law, K. S. and Stohl, A.: Arctic Air Pollution: Origins and Impacts, Science, 315, 1537-1540, 2007.

Liggio, J. and Li, S.-M.: Organosulfate formation during the uptake of pinonaldehyde on acidic sulfate aerosols, Geophys. Res. Lett., 33, L13808, doi:10.1029/2006GL026079, 2006.

Lubin, D. and Simpson, A. S.:The longwave emission signature of urban pollution - radiometric FTIR measurement, Geophys. Res. Lett., 21, 37-40, 1994.

Mareckova, K., Wankmueller, R., Anderl, M., Muik, B., Poupa, S., and Wieser, M.: Inventory review 2008: Emission data reported under the LRTAP convention and NEC directive status of gridded data, Technical report, EMEP Centre on Emission Inventories and Projections, Vienna, 2008.

Nguyen, Q. T., Skov, H., Sørensen, L. L., Jensen, B. J., Grube, A. G., Massling, A., Glasius, M., and Nøjgaard, J. K.: Source apportionment of particles at Station Nord, North East Greenland during 2008-2010 using COPREM and PMF analysis, Atmos. Chem. Phys., 13, 35-49, doi:10.5194/acp-13-35-2013, 2013.

Petzold, A. and Schönlinner, M.: Multi-angle absorption photometry - a new method for the measurement of aerosol light absorption and atmospheric black carbon, J. Aerosol. Sci., 35, 421-441, 2004

Petzold, A., Kopp, C., and Niessner, R.: The dependence of the specific attenuation cross-section on black carbon mass fraction and particle size, Atmos. Environ., 31, 661-672, 1997.

Petzold, A., Kramer, H., and Schönlinner, M.: Continuous measurement of atmospheric black carbon using a multi-angle absorption photometer, Environ. Sci. Pollut. Res., 4, 78-82, 2002.

Petzold, A., Ogren, J. A., Fiebig, M., Laj, P., Li, S.-M., Baltensperger, U., Holzer-Popp, T., Kinne, S., Pappalardo, G., Sugimoto, N., Wehrli, C., Wiedensohler, A., and Zhang, X.-Y.: Recommendations for reporting "black carbon" measurements, Atmos. Chem. Phys., 13, 8365-8379, doi:10.5194/acp-13-83652013, 2013.

Quinn, P. K. and Bates, T. S.: The case against climate regulation via oceanic phytoplankton sulphur emissions, Nature, 480, 5156, 2011.

Quinn, P. K., Bates, T. S., Baum, E., Doubleday, N., Fiore, A. M., Flanner, M., Fridlind, A., Garrett, T. J., Koch, D., Menon, S., Shindell, D., Stohl, A., and Warren, S. G.: Short-lived pollutants in the Arctic: their climate impact and possible mitigation strategies, Atmos. Chem. Phys., 8, 1723-1735, doi:10.5194/acp8-1723-2008, 2008.

Raatz, W. E. and Shaw, G. E.: Long-range tropospheric transport of pollution aerosols into the Alaskan Arctic, J. Clim. Appl. Meteorol., 23, 1052-1064, 1984.

Roberts, D. L. and Jones, A.: Climate sensitivity to black carbon aerosol from fossil fuel combustion, J. Geophys. Res-Atmos., 109, D16202, doi:10.1029/2004JD004676, 2004.

Seinfeld, J. H. and Pandis, S. N.: Atmospheric chemistry and physics: from air pollution to climate change, 2nd Edn., WileyInterscience, New York, 2006.

Sharma, S., Brook, J. R., Cachier, H., Chow, J., and Lu, G.: Light absorption and thermal measurements of black carbon in different regions of Canada, J. Geophys. Res., 107, 4771, doi:10.1029/2002JD002496, 2002.
Sharma, S., Lavoue, D., Cachier, H., Barrie, L. A., and Gong, S. L.: Long-term trends of the black carbon concentrations in the Canadian Arctic, J. Geophys. Res.-Atmos., 109, D15203, doi:10.1029/2003JD004331, 2004.

Sharma, S., Andrews, E., Barrie, L. A., Ogren, J. A., and Lavoue, D.: Variations and sources of the equivalent black carbon in the high Arctic revealed by long-term observations at Alert and Barrow: 1989-2003, J. Geophys. Res.-Atmos., 111, D14208, doi:10.1029/2005JD006581, 2006.

Sharma, S., Ishizawa, M., Chan, D., Lavoue, D., Andrews, E., Eleftheriadis, K., and Maksyutov, S.: 16-year simulation of Arctic black carbon: Transport, source contribution, and sensitivity analysis on deposition, J. Geophys. Res.-Atmos., 118, 943-964, 2013.

Simpson, D., Benedictow, A., Berge, H., Bergström, R., Emberson, L. D., Fagerli, H., Flechard, C. R., Hayman, G. D., Gauss, M., Jonson, J. E., Jenkin, M. E., Nyíri, A., Richter, C., Semeena, V. S., Tsyro, S., Tuovinen, J.-P., Valdebenito, Á., and Wind, P.: The EMEP MSC-W chemical transport model - technical description, Atmos. Chem. Phys., 12, 7825-7865, doi:10.5194/acp-127825-2012, 2012.

Skov, H., Wahlin, P., Christensen, J., Heidam, N. Z., and Petersen, D.: Measurements of elements, sulphate and $\mathrm{SO}_{2}$ in Nuuk Greenland, Atmos. Environ., 40, 4775-4781, 2006.

Slinn, S. A. and Slinn, W. G. N.: Predictions for particle deposition on natural waters, Atmos. Environ., 14, 1013-1026, 1980.

Slinn, W. G. N.: Predictions for particle deposition to vegetative surfaces, Atmos. Environ., 16, 1785-1794, 1982.

Stohl, A.: Characteristics of atmospheric transport into the Arctic troposphere, J. Geophys. Res., 111, D11306, doi:10.1029/2005JD006888, 2006.

Stohl, A., Berg, T., Burkhart, J. F., Fjaeraa, A. M., Forster, C., Herber, A., Hov, Ø., Lunder, C., McMillan, W. W., Oltmans, S., Shiobara, M., Simpson, D., Solberg, S., Stebel, K., Ström, J., Tørseth, K., Treffeisen, R., Virkkunen, K., and Yttri, K. E.: Arctic smoke - record high air pollution levels in the European Arctic due to agricultural fires in Eastern Europe in spring 2006, Atmos. Chem. Phys., 7, 511-534, doi:10.5194/acp-7-511-2007, 2007.

Stohl, A., Klimont, Z., Eckhardt, S., Kupiainen, K., Shevchenko, V. P., Kopeikin, V. M., and Novigatsky, A. N.: Black carbon in the Arctic: the underestimated role of gas flaring and residential combustion emissions, Atmos. Chem. Phys., 13, 8833-8855, doi:10.5194/acp-13-8833-2013, 2013.

Strand, A. and Hov, O.: A 2-Dimensional Global Study of Tropospheric Ozone Production, J. Geophys. Res.-Atmos., 99, 2287722895, 1994.

Surratt, J. D., Kroll, J. H., Kleindienst, T. E., Edney, E. O., Claeys, M., Sorooshian, A., Ng, N. L., Offenberg, J. H., Lewandowski, M., Jaoui, M., Flagan, R. C., and Seinfeld, J. H.: Evidence for organosulfates in secondary organic aerosol, Environ. Sci. Technol., 41, 517-527, 2007.

Swietlicki, E., Hansson, H.-C., Hämeri, K., Svenningsson, B., Massling, A., McFiggans, G., McMurry, P. H., Petäjä, T., Tunved, P., Gysel, M., Topping, D., Weingartner, E., Baltensperger, U., Rissler, J., Wiedensohler, A., and Kulmala, M.: Hygroscopic properties of sub-micrometer atmospheric aerosol particles measured with H-TDMA instruments in various environments - a review, Tellus B, 60, 432-469, 2008. 
van der Werf, G. R., Randerson, J. T., Giglio, L., Collatz, G. J., Mu, M., Kasibhatla, P. S., Morton, D. C., DeFries, R. S., Jin, Y., and van Leeuwen, T. T.: Global fire emissions and the contribution of deforestation, savanna, forest, agricultural, and peat fires (19972009), Atmos. Chem. Phys., 10, 11707-11735, doi:10.5194/acp10-11707-2010, 2010.

Vignati, E., Karl, M., Krol, M., Wilson, J., Stier, P., and Cavalli, F.: Sources of uncertainties in modelling black carbon at the global scale, Atmos. Chem. Phys., 10, 2595-2611, doi:10.5194/acp-102595-2010, 2010.
Wang, Q., Jacob, D. J., Fisher, J. A., Mao, J., Leibensperger, E. M., Carouge, C. C., Le Sager, P., Kondo, Y., Jimenez, J. L., Cubison, M. J., and Doherty, S. J.: Sources of carbonaceous aerosols and deposited black carbon in the Arctic in winter-spring: implications for radiative forcing, Atmos. Chem. Phys., 11, 12453 12473, doi:10.5194/acp-11-12453-2011, 2011.

Yttri, K. E., Lund Myhre, C., Eckhardt, S., Fiebig, M., Dye, C., Hirdman, D., Ström, J., Klimont, Z., and Stohl, A.: Quantifying black carbon from biomass burning by means of levoglucosan - a one-year time series at the Arctic observatory Zeppelin, Atmos. Chem. Phys., 14, 6427-6442, doi:10.5194/acp-14-64272014, 2014. 